\title{
Effects of mercerization in the chemical and morphological properties of amazon piassava
}

\author{
Viviane Rebelo ${ }^{1}$, Yuri da Silva ${ }^{1}$, Saulo Ferreira ${ }^{2}$, Romildo Toledo Filho ${ }^{2}$ and Virginia Giacon ${ }^{1 *}$ \\ ${ }^{1}$ Programa de Pós-graduação em Engenharia Civil, Faculdade de Tecnologia - FT, \\ Universidade Federal do Amazonas - UFAM, Manaus, AM, Brasil \\ ${ }^{2}$ Departamento de Engenharia Civil, Instituto Alberto Luiz Coimbra de Pós-graduação e Pesquisa de \\ Engenharia - COPPE, Universidade Federal do Rio de Janeiro - UFRJ, Rio de Janeiro, RJ, Brasil \\ *giacon@ufam.edu.br
}

\begin{abstract}
The objective of this work was to investigate the effects of mercerization on chemical, morphological and thermal properties of Amazon Piassava Fibers. The effect of this treatment was studied using XRF, SEM, XRD and TGA. The fibers have been treated in $5 \%$ and $10 \% \mathrm{NaOH}$ for $60 \mathrm{~min}$. The XRF results for treated and untreated fibers showed that there is a decrease in the amount of $\mathrm{SiO}_{2}$ by increasing the $\mathrm{NaOH}$ concentration. It has been possible to observe through SEM in untreated fiber that the surface presents a well arranged pattern of silicon rich star-like protrusions. For the two concentrations, SEM allowed to notice that the removal of deleterious surface impurities and fiber roughness was enhanced. The removal of organic material after treatment can be observed in the TGA analysis. XRD analysis indicate an increase in the crystallinity index, 0.19 to 0.31 after the treatment for $10 \%$ concentration solutions.
\end{abstract}

Keywords: alkaline treatment, mercerization, piassava fibers, superficial modification.

How to cite: Rebelo, V., Silva, Y., Ferreira, S., Toledo Filho, R., \& Giacon, V. (2019). Effects of mercerization in the chemical and morphological properties of amazon piassava. Polimeros: Ciência e Tenologia, 29(1), e2019013. https:// doi.org/10.1590/0104-1428.01717

\section{Introduction}

The increasing global demand for consumer goods has exerted a rising pressure on the Earth's resource consumption. This has led to increased interest in the development of sustainable materials ${ }^{[1]}$.

Among such renewable resources are the lignocellulosic materials or vegetable fibers. Brazil, specifically the Amazon region, is rich in renewable resources and possesses wide variety of vegetable fibers ${ }^{[2]}$.

As a result, the use of natural fibers as a viable reinforcement in composite materials is increasing and has gained a significant research interest, possibly due to features like high specific modulus, non-toxicity, biodegradability, low cost and abundance ${ }^{[3]}$. Natural fibers like flax, hemp, jute and sisal have been well known as potential adequate reinforcements for engineering fiber composites ${ }^{[4-8]}$. Nevertheless, the Piassava Fiber (Leopoldinia Piassaba) in despite of their availability in Amazon, has been used mainly as raw material in craft and as home utensils as brooms or brushes and there is a lack of specific studies focused on Piassava Amazon fiber uses and their properties in composites materials.

On the other hand, the issue of fiber-matrix interaction in composites materials has received increasing attention. However, natural fibers have structural compounds (cellulose, hemicelluloses, lignin and other substances) that allow moisture absorption from the environment. The interaction between the hydrophilic fibers and their hydrophobic matrix

causes fiber swelling within the matrix ${ }^{[9]}$. This results in the weakening of bonding strength at the interface, therefore leading to dimensional instability, matrix cracking and poor mechanical properties of the composites ${ }^{[10,11]}$.

In order to enhance the effectiveness of interfacial bonding between fiber and matrix, fiber surface needs to be modified. There are many types of treatments, such as, for instance, sodium hydroxide $(\mathrm{NaOH})$ or mercerization, which is being widely used to modify the cellulosic molecular structure $^{[5,12]}$. According to John, 2007, This modification promotes the access to penetrate chemicals causing reaction with water molecules and move out them from the fibre structure, while the remaining reactive water molecules form fibre-cell-O-Na bonds ${ }^{[1]}$. This process increase the fibres moisture resistance property due to reduction of hydropylic hydrowyl groups ${ }^{[10,13]}$. Besides, another important modification done by mercerization is the increase in the surface roughness caused by the disruption of hydrogen bonding in the network structure. Consequently, there is improvement in the composite mechanical properties ${ }^{[6,14]}$.

The main objective of the present study consists of clarifying the effect of mercerization on chemical, morphological and thermal properties of the Amazon Piassava Fibers (Leopoldinia piassaba), filling the gap of information about the surface modifications after the treatment, which could improve the interface adhesion between Amazon Piassaba Fiber and polymer matrix 


\section{Materials and Methods}

\subsection{Materials}

The Piassava fibers used in the present investigation were purchased from O.A. NunesNeta - ME (Brazilian company), located in Manaus. The fibers presented a moisture content of $13 \%$, measures in laboratory. The $\mathrm{NaOH}$ was obtained by Nuclear Company, supplier Instrumental Technical Ltda, Manuas-Am.The fibers were cut at a nominal length of $1 \mathrm{~cm}$.

\subsection{Methods}

\subsubsection{Mercerization}

For mercerization treatment, a commercial $\mathrm{NaOH}$ solution was used.

The fibers were cut at a nominal length of $1 \mathrm{~cm}$ and soaked in two different $\mathrm{NaOH}$ concentrations $(5 \%$ and $10 \%$ by weight) for $60 \mathrm{~min}$. Then, the fibers were rinsed several times with water to remove the excess $\mathrm{NaOH}$ solution, until achieving $\mathrm{pH} 7$, and afterwards dried at room temperature conditions of $36{ }^{\circ} \mathrm{C}$ for $24 \mathrm{hrs}$ to remove excess water. The effects of the mercerization in the fibers were investigated using the following techniques: XRF, SEM, XRD and TGA.

\subsubsection{Ray Fluorescence (XRF)}

The measurements of the sample elemental composition were performed through the X-ray fluorescence (XRF) technique using an Epsilon3-XL spectrometer (PANalytical) with $15 \mathrm{~W}$ maximum power. A semiquantitative analysis of the spectra was performed with the Omnian package.

\subsubsection{Scanning Electron Microscopy (SEM)}

The piassava fiber's microstructure was investigated using an SEM Hitachi TM3000. The microscope was operated under an accelerating voltage of $15 \mathrm{kV}$. A pre-coating with a thin layer of approximately $20 \mathrm{~nm}$ of gold was done to make the fiber conductive and suitable for analysis.

\subsubsection{Ray Diffraction (XRD)}

$\mathrm{X}$-ray diffraction studies were performed under ambient condition in the equipment EMPYREAM PIXcel 3D

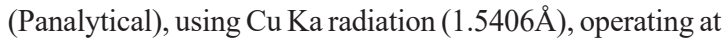
$40 \mathrm{Kv}$ and current of $40 \mathrm{Ma}$. The scan was taken at a range of $5^{\circ}<2 \theta<45^{\circ}$ at a rate of $1 \%$ min and step size $0.0001^{\circ}$. Crystallinity index (Ic) and percentage crystallinity $(\% \mathrm{Cr})$ were calculated using Equations 1 and $2^{[15,16]}$ :

$$
\begin{aligned}
& C r \%=\frac{I_{22}}{I_{22}+I_{18}} x 100 \\
& I c r=\frac{I_{22}-I_{18}}{I_{22}}
\end{aligned}
$$

The method was for empirical measurements to allow rapid comparison of samples, where $\mathrm{I}_{22}$ and $\mathrm{I}_{18}$ are the crystalline and amorphous intensities at $2 \theta$ scale to $22^{\circ}$ and $18^{\circ}$, respectively ${ }^{[17,18]}$.

\subsubsection{Thermo Gravimetric Analysis (TGA)}

Thermal analysis of fibers (TGA/DTGA) was performed in natural and treated fibers. The tests were performed in a SDT Q600 simultaneous TGA/DTA/DSC from TA Instruments. Samples weighing $10 \mathrm{mg}$ were submitted to a heating rate of $10{ }^{\circ} \mathrm{C} / \mathrm{min}$ until reaching $600^{\circ} \mathrm{C}$ in a platinum crucible using $100 \mathrm{ml} / \mathrm{min}$ of nitrogen as the purge gas.

\section{Results and Discussions}

The XRF results are shown in Table 1. After the mercerization process, there is a decrease of the $\mathrm{SiO}_{2}$ content from $34.9 \%$ of the natural fiber to $9.6 \%$ and $6.6 \%$ for 5 and $10 \%$ concentration solutions, respectively. The treatment processes can enhance removal of surface impurities and increase fiber roughness. This is advantageous for fiber to matrix adhesion as it facilitates mechanical interlocking from the increased surface area available for contact with the matrix and improves the composites mechanical properties ${ }^{[19]}$.

Moreover, Table 1 shows that after the treatment there is presence of sodium in the fiber. This is possible since the treatment changes the fiber structure and there is the reaction of sodium hydroxide with cellulose. This reaction is shown in Equation $3^{[3]}$.

$$
\begin{aligned}
& \text { Cellulose }-\mathrm{OH}+\mathrm{NaOH} \rightarrow \text { Cellulose }- \\
& \mathrm{O}^{-} \mathrm{Na}^{+}+\mathrm{H}_{2} \mathrm{O}+\text { Surface Impurities }
\end{aligned}
$$

Figure 1 shows SEM micrographs of the fiber surface morphology and the protrusions, which are Si rich particles ${ }^{[20,21]}$.

The surface topography of piassava (Fib 2b) is rougher than before treatment (Figure $2 \mathrm{a}$ ) and the surface looks cleaner. This occurs because the mercerization removes lignin, pectin, waxy substances, and natural oils that cover the external surface of the fiber cell wall, revealing the fibrils,



Figure 1. SEM of piassava fiber untreated: protrusions.

Table 1. Chemical elements presentin the untreated and treated Piassava fiber samples obtained by the X-ray fluorescence.

\begin{tabular}{cccc}
\hline Element & Fiber in Natura (w.\%) & $\mathbf{5 \%} \mathbf{N a O H}(\mathbf{w . \%})$ & $\mathbf{1 0 \%} \mathbf{N a O H}(\mathbf{w} . \%)$ \\
\hline $\mathrm{Na}$ & $\mathbf{0 . 0 0 0}$ & $\mathbf{8 . 4 3 5}$ & $\mathbf{2 2 . 8 4 2}$ \\
$\mathrm{Mg}$ & 0.541 & 0.026 & 0.169 \\
$\mathrm{Al}$ & 21.109 & 6.491 & 8.194 \\
$\mathrm{Si}$ & $\mathbf{3 4 . 9 6 5}$ & $\mathbf{9 . 6 6 4}$ & $\mathbf{6 . 6 6 8}$ \\
\hline
\end{tabular}


resulting in a rough surface topography of the fiber ${ }^{[3,21]}$. Then, with the higher solution concentration there is a roughness increase (Figure 3a and 3b).

Figure 4a shows the transversal cross-section of the untreated piassava sample. After treatment (Figure 4b), the cell wall thicknessvaried from $3 \mu \mathrm{mto} 1 \mu \mathrm{m}$, which can be attributed to the removal of organic materials, suchas lignin and other substances ${ }^{[3]}$.

The results of the thermogravimetric analysis are presented in Figure 5. It is possible to observe in the untreated fiber decomposition behavior a small low temperature weight loss (11.88\%), between 25 and $112^{\circ} \mathrm{C}$, that can be attributed to water in the form of absorbed moisture or combined water ${ }^{[22]}$. The onset of the fiber thermal degradation began at about $180{ }^{\circ} \mathrm{C}$, with the decomposition of hemicellulose. According to the literature ${ }^{[11]}$, the TGA curve of hemicellulose presented three stages of decomposition (from 25 to $180^{\circ} \mathrm{C}$, from 180 to $280^{\circ} \mathrm{C}$ and 280 to $500{ }^{\circ} \mathrm{C}$ ). The peak at $361^{\circ} \mathrm{C}$ could be associated with the decomposition of cellulose.
This value is higher than the reported for the pure cellulose sample ${ }^{[11]}$ and the piassava (Attaleafunifera $)^{[10]}$. The thermal decomposition of lignin ranged from 150 to $450{ }^{\circ} \mathrm{C}^{[11]}$ and is dependent on specie. A clear peak for lignin was not observed in this curve.

From Figure 5 it is also possible to observe the TGA and DTGA curves for the mercerized fibers. The mercerized $(5-10 \% \mathrm{NaOH})$ fibers showed lower decomposition temperatures compared to the untreated fiber. For the main fiber decomposition region $\left(200-400^{\circ} \mathrm{C}\right)$, the treated fibers had a higher weight loss than the untreated fiber, indicating lower thermal stability. This is probably due to the removal of organic materials such as lignin,pectin, waxy substances, and natural oils, evident in the curves of DTGA for mercerized fibers, where the peak around $250{ }^{\circ} \mathrm{C}$ was not visible, indicating the removal of hemicellulose from the fiber ${ }^{[3,23]}$.

To study the effectiveness of chemical treatment in piassaba fibers, XRD analysis was performed whose result is shown in the diffractogramin Figure 6.The figure shows

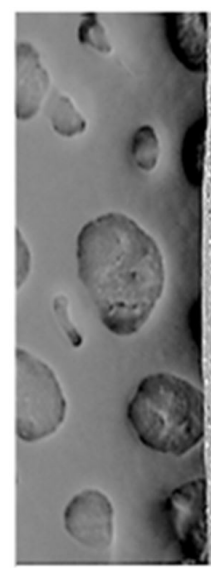

NUMATS.PECOSs9

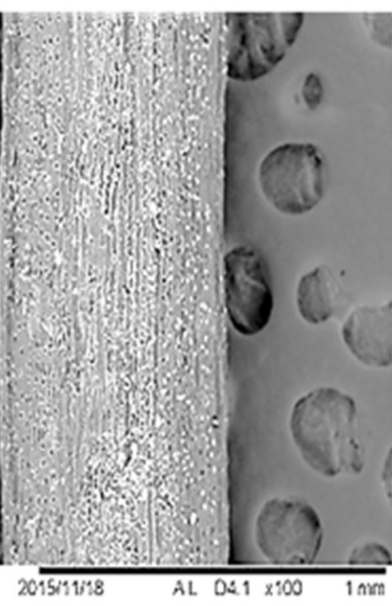

a)

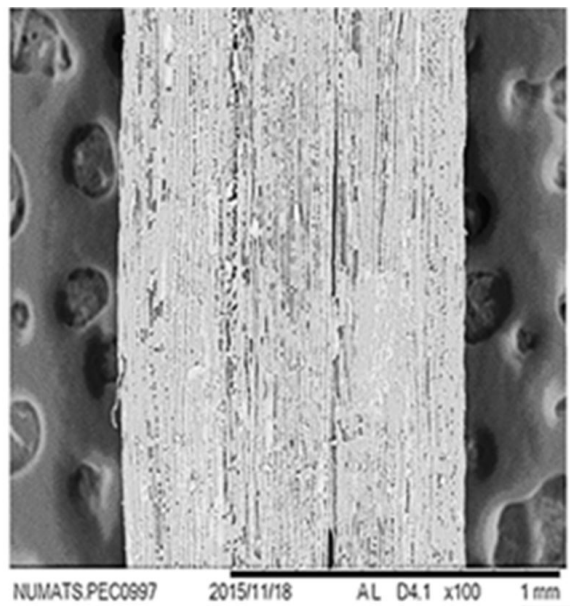

b)

Figure 2. SEM of piassava fiber (a) untreated; (b) $5 \% \mathrm{NaOH}$ treated.

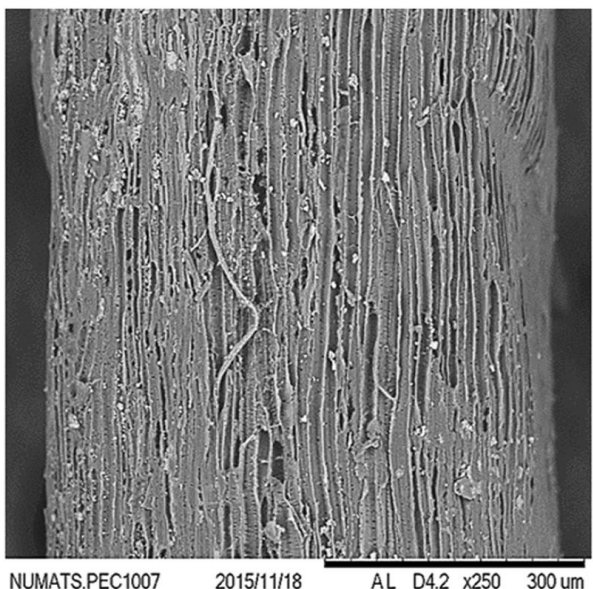

a)

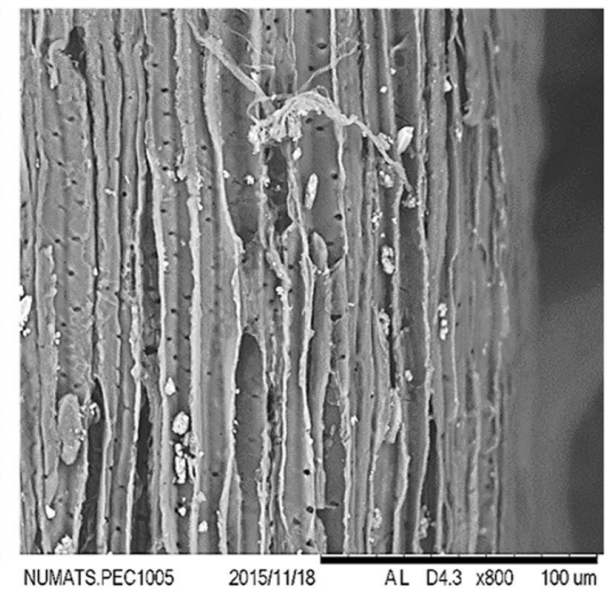

b)

Figure 3. SEM of piassava fiber treated $10 \% \mathrm{NaOH}$, view of fibrils (a) x250; (b) x800. 


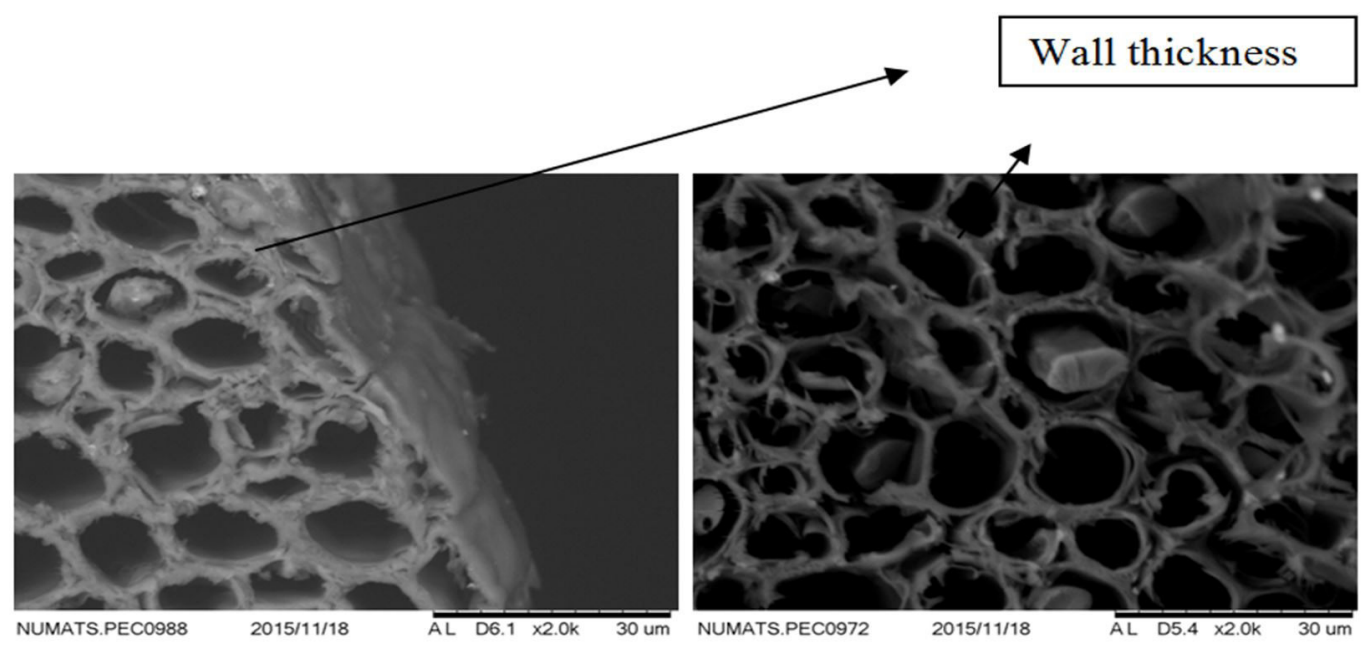

a)

b)

Figure 4. SEM of transversal cross-section piassava fiber (a) untreated; (b) $10 \% \mathrm{NaOH}$.

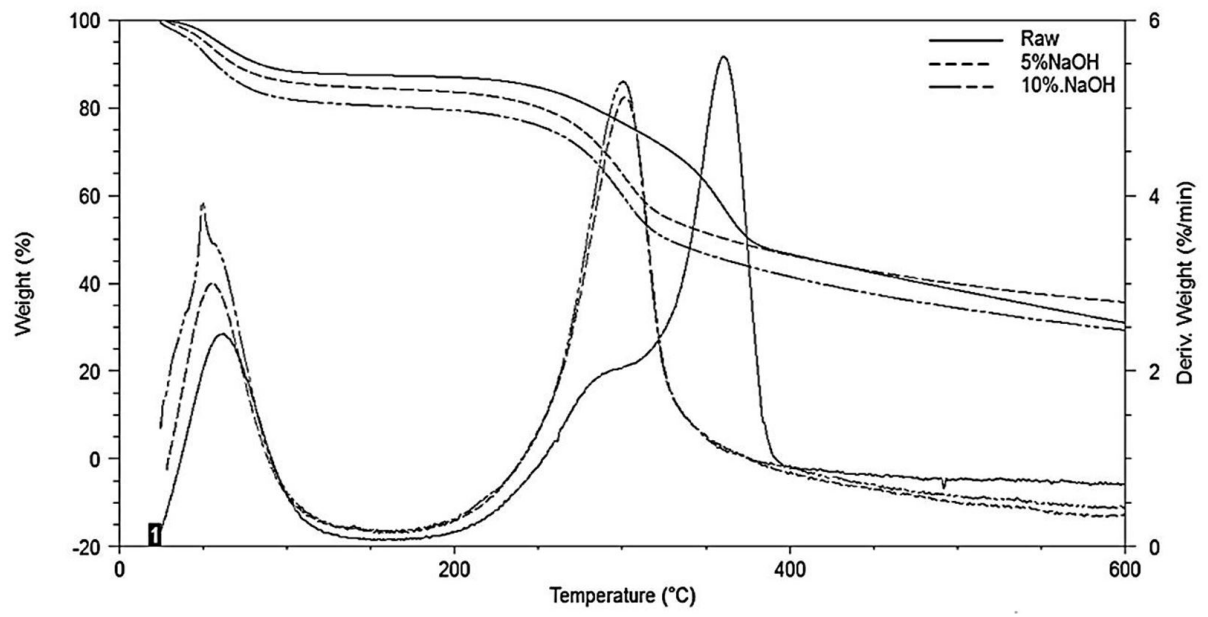

Figure 5. TGA and DTGA curves for treated and untreated fiber.

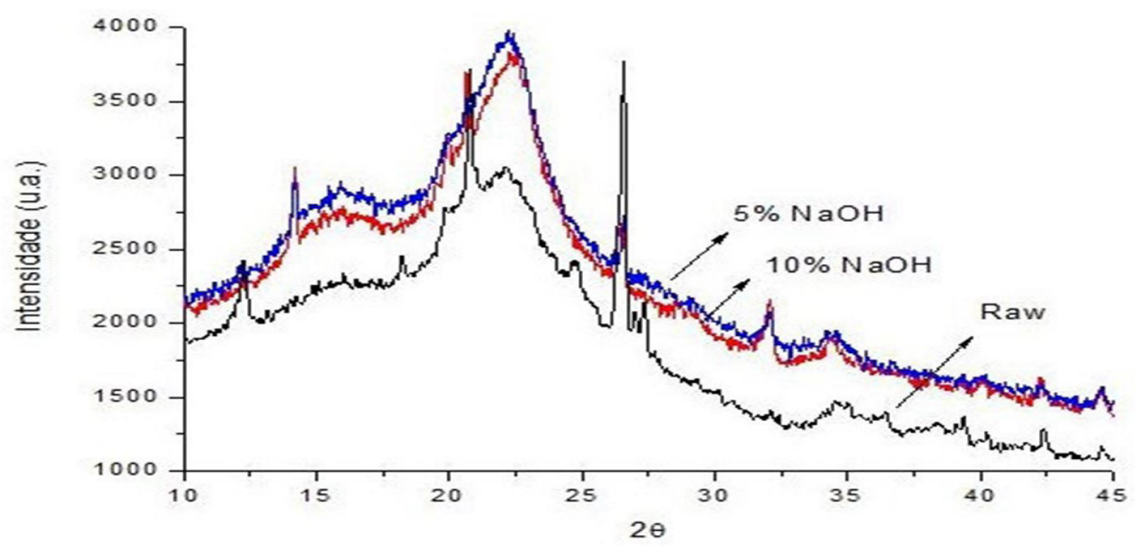

Figure 6. XRD curves of piassava fibers treated and untreated. 
Table 2. XRD data of raw and chemical treated piassava fibers.

\begin{tabular}{ccccc}
\hline Sample & $\mathbf{I}_{22}$ (at 20 scale) & $\mathbf{I}_{\mathbf{1 8}}$ (at 20 scale) & C.I. & \%Cr. \\
\hline Untreated & 3093.94 & 2499.56 & 0.19 & 55.31 \\
$\mathbf{5 \%} \mathbf{~ N a O H}$ & 3982.73 & 2790.97 & 0.30 & 58.79 \\
$\mathbf{1 0 \%} \mathbf{~ N a O H}$ & 3835.82 & 2615.45 & 0.31 & 59.45 \\
\hline
\end{tabular}

that piassava fiber (untreated and treated) there are three broad diffraction peaks at $2 \theta$, the most intense being the $22^{\circ}$ corresponding to the crystalline part of the fiber, and halos at $16^{\circ}$ and $35^{\circ}$ referring to the amorphous part of the fiber, such as the hemicellulose and lignin present in the fibers microfibrils. The result obtained is very similar to those of other lignocellulosic fibers, and reflects the crystalline lattice of cellulose ${ }^{[24-28]}$.

Table 2 shows the results of percentage crystallinity $(\% \mathrm{Cr})$ and crystallinity index (C.I) of untreated and treated piassava fiber. The untreated fiber at $2 \theta$ scale gave peaks at 22.0 and 18.0 with relative intensity is 3093.94 and 2499.56 . Percentage crystallinity $(\% \mathrm{Cr})$ and crystallinity index (C.I) of untreated piassava fiber are 55.31 and 0.19 respectively whereas percentage crystallinity of alkali treated fibers (5\% and $10 \%$ ) were 58.79 and 59.41 . Whereas crystallinity index of alkali treated fibers are 0.30 and 0.31 respectively.

The increase of crystallinity index in alkaline treated piassava fibers indicated that the chemical treatment induced the crystallinity and it increase due to the removal of amorphous materials like hemicellulose, lignin, and some other ${ }^{[23,29-31]}$.

Through alkalization, an increase of composite quality is to be expected due to the improved fibre-matrix adheshion ${ }^{[5]}$.

\section{Conclusions}

The effects of mercerization on the amazon piassava (Leopoldinia piassaba) were presented. The results of the $\mathrm{XRF}$ showed that there is a higher sodium concentration when the fiber is treated with the $10 \% \mathrm{NaOH}$ solution. The fibers present silicon rich star-like protrusions that are removed after the mercerization process. XRD revealed increase in the crystallinity index due to the removal of amorphous materials like hemicellulose, lignin, and some other.

The fiber surface appears cleaner and rougher after the treatment. Thermal analysis of treated fibers displays lower thermal stability compared to the untreated fibers. These surface modifications could improve the interface adhesion between fiber and matrix, resulting in composites with enhanced mechanical properties.

\section{Acknowledgements}

The authors thank the Brazilian Agency Coordenação de Aperfeiçoamento de Pessoal de Nível Superior-CAPES for the support.

\section{References}

1. Gurunathan, T., Mohanty, S., \& Nayak, S. K. (2015). A review of the recent developments in biocomposites based on natural fibers and their application perspectives. Composites. Part A, Applied Science and Manufacturing, 77, 1-25. http://dx.doi. org/10.1016/j.compositesa.2015.06.007.
2. Satyanarayana, K. G., Guimaraes, J. L., \& Wypych, F. (2007). Studies on lignocellulosic fibers of Brazil. Part I: source, production, morphology, properties and applications. Composites. Part A, Applied Science and Manufacturing, 38(7), 1694-1709. http://dx.doi.org/10.1016/j.compositesa.2007.02.006.

3. Mwaikambo, L. Y., \& Ansell, M. P. (2002). Chemical modification of hemp, sisal, jute, and kapok fibers by alkalization. Journal of Applied Polymer Science, 84(12), 2222-2234. http://dx.doi. org/10.1002/app.10460.

4. Milanese, A. C., Cioffi, M. O. H., \& Voorwald, H. J. C. (2011). Mechanical behavior of natural fiber composites. Engineering Procedia, 10, 2022-2027. http://dx.doi.org/10.1016/j. proeng.2011.04.335.

5. Bledzki, A. K., \& Gassan, J. (1999). Composites reinforced with cellulose based fibers. Progress in Polymer Science, 24(2), 221-274. http://dx.doi.org/10.1016/S0079-6700(98)00018-5.

6. Arrakhiz, F. Z., El Achaby, M., Kakou, A. C., Vaudreuil, S., Benmoussa, K., Bouhfid, R., Fassi-Fehri, O., \& Qaiss, A. (2012). Mechanical properties of high density polyethylene reinforced with chemically modified coir fibers: impact of chemical treatments. Materials \& Design, 37, 379-383. http:// dx.doi.org/10.1016/j.matdes.2012.01.020.

7. Fiorelli, J., Curtolo, D. D., Barrero, N. G., Savastano, H. Jr, Pallone, E. M. J. A., \& Johnson, R. (2012). Particulate composite based on coconut fiber and castor oil polyurethane adhesive: an eco-efficient product. Industrial Crops and Products, 40(10), 69-75. http://dx.doi.org/10.1016/j.indcrop.2012.02.033.

8. Sethi, S., \& Ray, B. C. (2015). Environmental effects on fiber reinforced polymeric composites Evolving reasons and remarks on interfacial strength and stability. Advances in Colloid and Interface Science, 217, 43-67. http://dx.doi.org/10.1016/j. cis.2014.12.005. PMid:25578406.

9. Doan, T. T. L., Gao, S. L., \& Mader, E. (2006). Jute polypropylene composites I: effect of matrix modification. Composites Science and Technology, 66(7-8), 952-963. http://dx.doi.org/10.1016/j. compscitech.2005.08.009.

10. Li, X., Tabil, L. G., \& Panigrahi, S. (2007). Chemical treatments of natural fiber for use in natural fiber- reinforced composites: a review. Journal of Polymers and the Environment, 15(1), 25-33. http://dx.doi.org/10.1007/s10924-006-0042-3.

11. Kabir, M. M., Wang, H., Lau, K. T., \& Cardona, F. (2012). Chemical treatments on plant based natural fiber reinforced polymer composites: an overview. Composites. Part B, Engineering, 43(7), 2883-2892. http://dx.doi.org/10.1016/j. compositesb.2012.04.053.

12. Mohan, T. P., \& Kanny, K. (2012). Chemical treatment of sisal fiber using alkali and clay method. Applied Science and Manufacturing, 43(11), 1989-1998. http://dx.doi.org/10.1016/j. compositesa.2012.07.012.

13. John, M. J., \& Anandjiwala, R. D. (2007). Recent developments in chemical modification and characterization of natural fiberreinforced composites. Polymer Composites, 29(2), 187-207. http://dx.doi.org/10.1002/pc.20461.

14. Reis, J. M. L., \& Motta, E. P. (2014). Mechanical behavior of piassava fiber reinforced castor oil polymer mortars. Composite Structures, 111(1), 468-472. http://dx.doi.org/10.1016/j. compstruct.2014.01.023.

15. Segal, L., Creely, J. J. Jr, Martin, A. E. Jr, \& Conrad, C. M. (1959). An empirical method for estimating the degree of 
crystallinity of nature cellulose using the X-ray diffractometer. Textile Research Journal, 29(10), 786-794. http://dx.doi. org/10.1177/004051755902901003.

16. Calado, V., Barreto, D. W., \& D'almeida, J. R. M. (2000). The effect of a chemical treatment on the structure and morphology of coir fibers. Journal of Materials Science Letters, 19(23), 2151-2153. http://dx.doi.org/10.1023/A:1026743314291.

17. Park, S., Baker, J. O., Himmel, M. E., Parilla, A., \& Johnson, D. K. (2010). Cellulose crystallinity index: measurement techniques and their impact on interpreting cellulose performance. Biotechnology for Biofuels, 3(1), 10. http:// dx.doi.org/10.1186/1754-6834-3-10. PMid:20497524.

18. Kalia, S., \& Sheoran, R. (2011). Modification of ramie fibers using microwave-assisted grafting and cellulase enzyme-assisted biopolishing: a comparative study of morphology, thermal stability, and crystallinity. Journal of Polymer Analysis and Characterization, 16(5), 307-318. http://dx.doi.org/10.1080/ 1023666X.2011.587946.

19. Mokaloba, N., \& Batane, R. (2014). The effects of mercerization and acetylation treatments on the properties of sisal fiber and its interfacial adhesion characteristics on polypropylene. International Journal of Engineering Science and Technology, 6(4), 83-97. http://dx.doi.org/10.4314/ijest.v6i4.9.

20. D’Almeida, J. R. M., Aquino, R. C. M. P., \& Monteiro, S. N. (2006). Tensile mechanical properties, morphological aspects and chemical characterization of piassava (Attaleafunifera) fibers. Composites. Part A, Applied Science and Manufacturing, 37(9), 1473-1479. http://dx.doi.org/10.1016/j.compositesa.2005.03.035.

21. Nascimento, D. C. O., Ferreira, A. S., Monteiro, S. N., Aquino, R. C. M. P., \& Kestur, S. G. (2012). Studies on the characterization of piassava fibers and their epoxy composites. Composites. Part A, Applied Science and Manufacturing, 43(3), 353-362. http://dx.doi.org/10.1016/j.compositesa.2011.12.004.

22. Kabir, M. M., Wang, H., Lau, K. T., \& Cardona, F. (2013). Effects of chemical treatments on hemp fiber structure. Applied Surface Science, 276, 13-23. http://dx.doi.org/10.1016/j. apsusc.2013.02.086.

23. Zimmermann, E. G. M., Turell, T. C., Zattera, A. J., \& Santana, R. M. C. (2014). Influence of chemical treatment of banana fiber composite of poly (ethylene-co-vinyl acetate) with and without blowing agent. Journal of Polymer Science and Technology, 24(1), 58-64. http://dx.doi.org/10.4322/polimeros.2013.071.

24. Rong, M. Z., Zhang, M. Q., Liu, Y., Yang, G. C., \& Zeng, H. M. (2001). The effect of fiber treatment on the mechanical properties of unidirectional sisal-reinforced epoxy composites. Composites Science and Technology, 61(7-8), 1437-1447. http://dx.doi.org/10.1016/S0266-3538(01)00046-X.

25. Oudiani, A. E., Chaabouni, Y., Msahli, S., \& Sakli, F. (2011). Crystal transition from cellulose I to cellulose II in $\mathrm{NaOH}$ treated Agave americana L. fibre. Carbohydrate Polymers, 86(3), 1221-1229. http://dx.doi.org/10.1016/j.carbpol.2011.06.037.

26. Goswami, P., Blackburn, R. S., El-Dessouky, H. M., Taylor, J., \& White, P. (2009). Effect of sodium hydroxide pre-treatment on the optical and structural properties of lyocell. European Polymer Journal, 45(2), 455-465. http://dx.doi.org/10.1016/j. eurpolymj.2008.10.030.

27. Široký, J., Manian, A. P., Široká, B., Abu-Rous, M., Schlangen, J., Blackburn, R. S., \& Bechtold, T. (2009). Alkali treatments of lyocell in continuous processes. I. Effects of temperature and alkali concentration on the treatments of plain woven fabrics. Journal of Applied Polymer Science, 113(6), 3646-3655. http:// dx.doi.org/10.1002/app.30356.

28. Singh, V., Tiwari, A., Tripathi, D. N., \& Sanghi, R. (2004). Grafting of polyacrylonitrile onto guar gum under microwave irradiation. Journal of Applied Polymer Science, 92(3), 15691575. http://dx.doi.org/10.1002/app.20099.

29. Vijay, K. K., Anil, K., \& Susheel, K. (2012). Effect of mercerization and benzoyl peroxide treatment on morphology, thermal stability and crystallinity of sisal fibers. International Journal of Textile Science, 1(6), 101-105. http://dx.doi.org/10.5923/j. textile.20120106.07.

30. Gonçalves, A. P. B., Miranda, C. S., Guimarães, D. H., Oliveira, J. C., Cruz, A. M. F., Silva, F. L. B. M., Luporini, S., \& José, N. M. (2015). Physicochemical, mechanical and morphologic characterization of purple banana fibers. Materials Research, 18(2, Suppl 2), 205-209. http://dx.doi.org/10.1590/15161439.366414.

31. Geethamma, V. G., Joseph, R., \& Thomas, S. (1995). Short coir fibre reinforced natural rubber composites: effects of fibre length, orientation and alkali treatmant. Journal of Applied Polymer Science, 55(4), 583-594. http://dx.doi.org/10.1002/ app.1995.070550405.
Received: Jan. 23, 2018 Revised: Aug. 14, 2018 Accepted: Dec. 28, 2018 